\title{
THE ADEQUATE MANAGEMENT OF ENVIRONMENTAL ISSUES SPECIFIC TO RURAL COMMUNITIES IN ROMANIA - PREMISE OF NATURAL HERITAGE CONSERVATION AND OF LIFE QUALITY INCREASE
}

\author{
Doina Guta, Gheorghe Batrinescu, Blaziu Carol Lehr
}

National Research and Development Institute for Industrial Ecology - ECOIND, Bucharest, Romania, 71-73Drumul Podu Dambovitei St., Sect. 6, Zip Code 060652; Tel: 04.021.410.67.16; Fax: 04.021.410.05.75/ 412.00 .42

email: ecoind@incdecoind.ro; http: //www.incdecoind.ro

\begin{abstract}
:
In Romania, the disparities between urban and rural areas are much higher than in most European Union states. There are situations when public authorities, especially in rural areas, do not have the necessary capability to identify and solve a number of important specific problems of the communities that they manage, inclusive relating to environment. The EU has a common rural development policy which Romania, as a member country, should apply, and the environmental problems of rural communities are key components of this policy. As a result, the paper proposes a study regarding both existing status and solutions to solve environmental problems characteristic of rural area of Romania, which to underlie of a model for managing environmental issues specific to this space. Punctually, is about aspects regarding: environmental components and natural resources quality; waste and wastewater management; ecological agriculture; green energy sources; biodiversity and natural heritage; the landscape component. For the study, specific information were collected, processed, systematized and interpreted in correlation with the issues addressed so that it can be chosen an optimal model of management from several possible. The model will be a new and useful tool in the effort of rural local authorities willing to give due weight to preservation the natural heritage and improve quality of life.
\end{abstract}

Keywords: managing environmental issues, sustainable rural development, good environmental practices, natural heritage

\section{Introduction}

This paper is a synthetic study on state of affairs and possible solutions for solving the environmental problems specific to the rural area in Romania, to underpin a model for managing the specific environmental aspects of this space.

\section{Reasons for choosing work theme}

The need for a model for the management of environmental issues that are specific to rural communities in Romania is required for the following reasons:

- the existing situation (directly observable or obtained through documentation) on the living conditions and environmental issues specific to rural communities in Romania, reflecting a pace too slow development of Romanian rural areas and a discrepancy very high compared to most EU countries; 
- the need to respect the national and european existing laws on rural development and environmental protection;

- opportunities offered by various national and european programs and development and funding plans dedicated to rural and environmental problems they are facing and the difficulties of advantage of these opportunities.

\section{Rural area}

There are different ways that defined the rural areas. An official definition of rural is given by Recommendation 1296/1996 of the Council of Europe Parliamentary Assembly (held in 1996 in Strasbourg) on the European Charter of rural areas, as follows: "the expression <<rural area >> refers to an inner zone, including villages and small towns, in which most of the land are used for:

a) agriculture, forestry, aquaculture and fisheries;

b) economic and cultural activities of the inhabitants of these areas (crafts, industry, services, etc.);

c) Making non-urban areas for leisure and entertainment (or the natural reserves);

d) other uses (except residential)" [1]

In the European Union, rural areas of most Member States are in a proper state of normality of the XXI century in terms of the level of civilization. This space benefits, at least, by minimum conditions necessary for a civilized living (existence of centralized water supply systems, sewage, proper management of waste and wastewater, the effective use of agricultural land, the existence of good transport infrastructure, a nice aspect of rural etc.). And continually, it is envisaged its development and rural development programs are usually complex, considering, firstly, human resources, environmental values and cultural landscape, the ultimate goal of these programs being that rural areas to be able, in a sustainable way, to fulfill their functions in society.

In Romania, from a variety of reasons including inefficient public administrations, disparities between urban and rural space are much higher than in most European Union states. There are situations in which public authorities, especially those in rural areas, have no interest and / or the ability required to identify and solve a number of important issues of the communities they manage and, unfortunately, environmental issues are among most disadvantaged. At this situation contributes both poor control of observance of legislation in the field (which is not just specific rural local communities but the entire country), and the faulty way in which information arrives in rural areas and especially to the citizens. This should be the first beneficiaries of any ecological actions, and the citizen must know his obligations and the consequences of his actions, which are detrimental to the environment and, consequently, to the detriment of his own life. On the other side, the citizen is the one who can claim (but does not know how to proceed) the improper statements relating to environmental aspects that affect them in the most direct way, and who has right to request the improvement of this situation. It should 
also be noted that, considering that there are many opportunities for development in rural space, offered mainly by the European Union, for the overall development of this area, for the personal development of members of rural communities and, not least, to protect environment, communities of people from this space do not benefit or benefit far too little from these opportunities.

\section{Work methods}

To do the work were needed

- a documentary research on national and European legislative provisions in order to identify as many items necessary to include in a model for managing environmental issues specific to rural communities;

- documentary and field research to assess the state of fact regarding environmental aspects of rural communities materialized in case studies;

- identifying solutions for solving the environmental problems characteristic of rural areas, given the legislative provisions and at the same time, the opportunities offered by national and European plans and programs dedicated to environmental issues and rural development.

The environmental aspects and problems that were addressed were highlighted through tests and analysis; the results were evaluated by relating to the legislative stipulations.

The case studies were made for two communes in Dambovita county, on a development level typical for most rural communities in Southern Romania. Field works were made, there were discussions with local authorities and local citizens of these communities, the state of the roads, the appearance of the streams and general landscape, the existence (or lack thereof) of basic infrastructure, both civil and agricultural, etc. were observed first hand. Water samples from wells, streams and deep drilled shafts for centralized water supply systems, as well as soil samples were tested through a chemical analysis.

\section{Results}

The results of the analysis performed can be summarized as:

$>$ Database informational on the state of fact for environmental problems in rural communities, highlighted by reference to the legislative provisions in the field; for it was approached and studied:

- general aspects of Romanian rural area in the European context;

- general and specific environmental issues in the rural communities

$>$ Two case studies to reveal concrete environmental problems faced by the rural communities

$>$ Identifying environmental problems existing in rural communities in Romania

$>$ Solutions for solving the environmental problems identified. 


\section{European and national legislation of interest in connection to the subject of this study}

Since the 1970s, the European Union (EU) has initiated, established and developed laws to ensure the careful use of natural resources, in order to minimize the negative impact of production and consumption on the environment and to protect biodiversity and natural habitats. EU environmental legislation covers extensive aspects like waste management, air and water quality, the issue of greenhouse gas and toxic chemicals. Thus, regarding the environment, EU legislation targets: fighting climate change; durable development; waste management; air pollution; water protection and management; nature and biodiversity protection; soil protection; civil protection; noise pollution; environment: cooperation with third countries.

Other than legislative provisions, there are even programmes and strategies at a national level and, directly connected to the subject of this study and the currently existing opportunities, the following are worth mentioning:

$>$ The National Strategy for Durable Developement on the horizon of the years 2013-2020-2030. "The stategy proposes a vision of Romania's developement in the prospect of the following two decades, with objectives that roughly transcend electoral cycles and political prefferences:

- Horizon 2013: Organic incorporation of principles and practices for durable development within the the programs and public policies in Romania as a member state of the EU;

- Horizon 2020: Reaching the present medium level that EU countries have to the main indicators of durable development;

- Horizon 2030: Significantly closeness for Romania to the average level that European Union member states will have in that year, in terms of sustainable development." [1]

> The National Strategic Center for durable development of the agricultural food segment and rural areas during the 2014-2020-2030 interval (The National Strategic Rural Plan); among others, its priorities are:

- Ensuring a durable ecological balance in the rural;

- Preserving and protecting the renewable natural resources (soil, water, air, biodiversity) and durable use of agricultural natural resources, particularly soil, preserving biodiversity, applying policies regarding the attenuation of the climate change effects;

> Rural Development Strategy 2014 - 2020 - Europa 2020 sets targets in education, innovation, energy/environment, employment and social inclusion and improving competitiveness in general.

$\checkmark$ Infrastructure Mare Operational Programme (POIM) 2014-2020, which has 9 priority axes of which, for the present work, we are interested in:

$\checkmark$ AP4 - Protection of the environment and promoting efficient use of resources

$\checkmark$ AP5 - Protecting and preserving biodiversity, the decontamination of historic polluted sites and air quality monitoring 
AP6 - Promote the adaptation to climate change, risk prevention and management

\section{Environmental aspects specific to rural comunities}

The environmental aspects which were considered in the present study were those pertaining to:

- The quality of the environmental components (water, soil, air);

- The management of waste and waste water;

- Natural resources;

- Ecological agriculture (seen as a major contribution to durable development);

- Green energy sources;

- The preservation of biodiversity and the natural patrimony in general;

- The landscaping component of the environment;

\section{Analysis results and conclusions}

The documentation and the study cases, made in order to highlight environmental issues of rural communities and to identify solutions for them as groundwork for a management model for environmental problems typical in the rural areas, lead to the following conclusions:

The environment issue specific for the rural communities is complicated, according to:

- the multitude of environmental aspects which manifest themselves at this level (in relation to the quantity and quality of rural infrastructure and environment, the type af agriculture practiced, the management of waste, the management of local resources, the need to maintain the countryside and biodiversity etc.);

- the level of development of rural communities in Romania;

- the legislation abundance and, in a great measure, the lack of implementing rules;

- the failure to comply with legislation and lack of compliance control with it;

- the opportunities for the reduction/resolution of environmental issues (national or european programs, plans, strategies etc.) and the difficulties to accede to these opportunities.

The main problems identified regarding the environment, specific to the Romanian rural area are:

- the failure to comply with environmental legislation;

- the failure to enforce the environmental legislation;

- the shortage of means for monitoring environmental components;

- the basic rural infrastructure is nonexistent or poorly developed (paved roads, potable water centralized systems, sewage systems, wastewater treatment systems, natural gas supply, eco-friendly units for temporary storage of waste), which affects the quality of water, air, soil and, directly or consequentially, human health;

- poorly developed agricultural infrastructure (irrigation systems, suitable storage platforms for animal waste, appropriate roads for moving agricultural machinery etc); 
- the use on farmlands, for the dual purpose of fertilization and irrigation, of sludge and wastewater from livestock and the excessive discharge of manure (over $100 \mathrm{t} / \mathrm{ha}$ ) on farmlands that are adjacnet to livestock farms/breeding complexes, containing hamrful salts and pathogen contaminants dangerous for soil, plants, animals and humans;

- the intensity of livestock activity, that poses the question of storing/disposing of waste and specific wastewater, enhances the emission of greenhouse gases etc.;

- intensive agriculture, which leads to the over-exploitation of the soil and the need for soil rehabilitation by use of irrationally applied inputs;

- the improper disposal and/or storage of household waste and those from livestock activity;

- lack of implementation of integrated waste management, starting with their non- selectively collection;

- lack of capitalization by composting of organic waste from households;

- uncontrolled discharge of waste water resulting from the activities of cattle breeding, household and from the maintenance of hygiene;

- deforestation and soil erosion;

- the weak development of ecological agriculture, although its dynamics is positive;

- significant areas of farmland and forest affected by adverse weather conditions (deficiency or excess water) or fallow;

- very low level of capitalization of the natural heritage;

- reduction of biodiversity due to increased human impact on the biosphere;

- inadequate management of the Natura 2000 network of protected natural areas and

lack of interest in the preservation, maintenance and rural arrangement of the space;

- lack or weak interest for natural heritage conservation;

- public advisory system insufficiently developed and not adapted to market demand and not enough addressed to users for agricultural and forest land;

- low level of education and vocational training, especially ongoing training in agriculture, forestry, animal husbandry, environment;

- high percentage of elderly farmers and migration of young people from rural areas;

- use not too much of the opportunities offered by national and European programs and plans for the development of rural areas and for reduction/solving environmental problems $[2,3,4,5,6,7,8,9,10,11]$.

At these conclusions on the general state of romanian rural area in terms of environmental issues are added the negative punctual conclusions resulting from the case studies:

- poor condition or lack of urban infrastructure: roads, sewerage, rainwater collection systems, gas supply networks, stations for temporary storage of household waste;

- poor condition or lack of agricultural infrastructure (irrigation system, roads in agricultural fields, ecological platforms for storage of animal wastes); 
- improper storage of cattle breeding waste (fig. no 1);

- practicing agriculture on fragmented agricultural land, uncontrolled application of fertilizer and other inputs on the land;
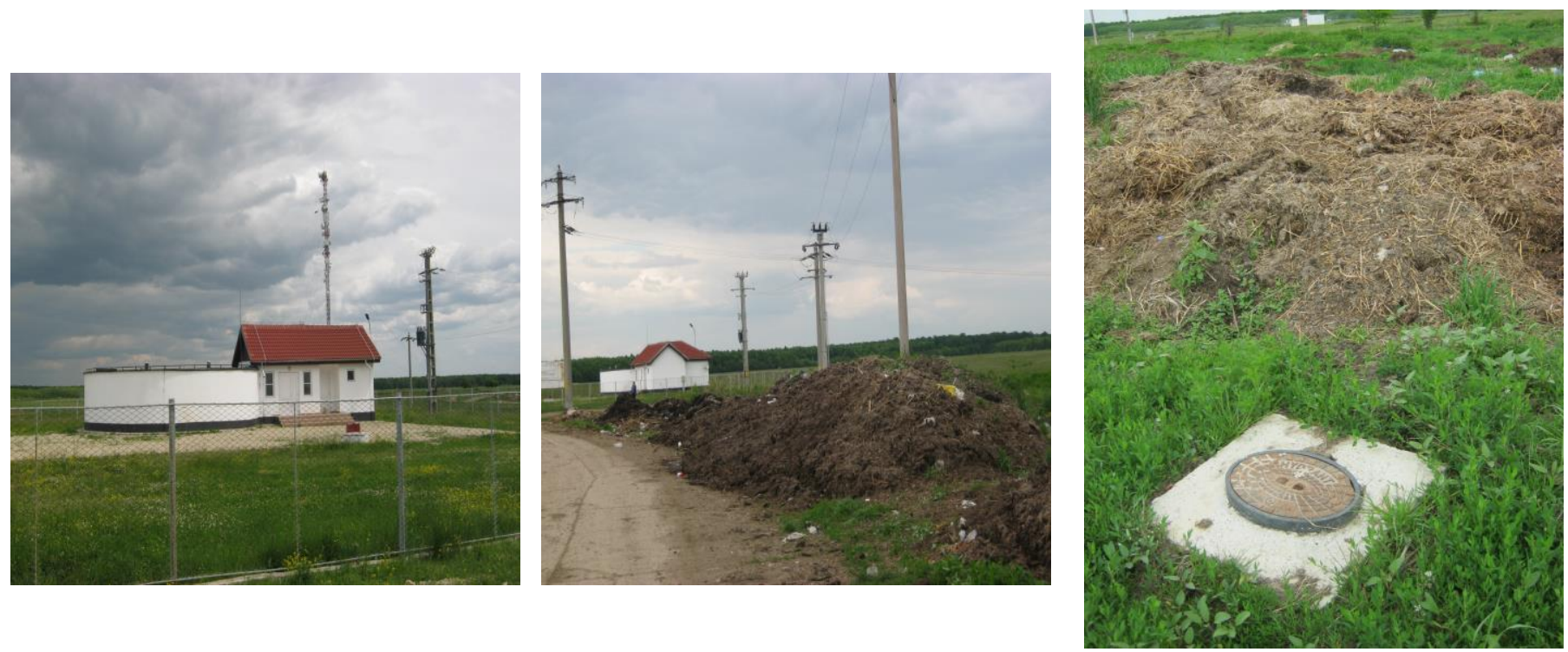

Fig. no. 1 - The location of the water supply station in one of the villages studied

- lack of vegetation shelterbelts, at the border with road transport routes, especially, both in the field and in households;

- inadequate state of water from fountains (bacteriological infection, mainly, and the presence of nitrates) and the low number of households connected to the water supply networks;

- the lack of any initiative on the monitoring, promotion and protection of Natura 2000 site - the Lunca of Middle Arges;

- the lack of interest regarding the look of the landscape and the valorisation of natural resources for tourism and recreation;

- inadequate appearance of some of the water courses that cross the villages studied and their partial clogging because the zootechnics and the domestic waste are thrown in their bed (Fig. no.2);

- poor quality of water in the most rivers crossing the commune, improper for bathing, because of the nitrate and nitrite content and of the microbiological level.

Of the solutions to the environmental problem, we mention:

- seriously implementation of the European legislation in the field of environment, development of rules for its application as completely as possible and clear;

- adoption and implementation of legislative provisions by all those involved, more or less directly, in environmental issues;

- existence around local authority decision-makingof a specialist or team in environmental issues, who knows well both the legislation and current strategies in the field; 
- correct identification of environmental problems and the solutions, involving specialists in the field;

- compliance control of environmental and legal measures in case of nonobservance

- increasing awareness about environmental issues;

- citizen involvement in environmental issues to develop the sense of responsibility;
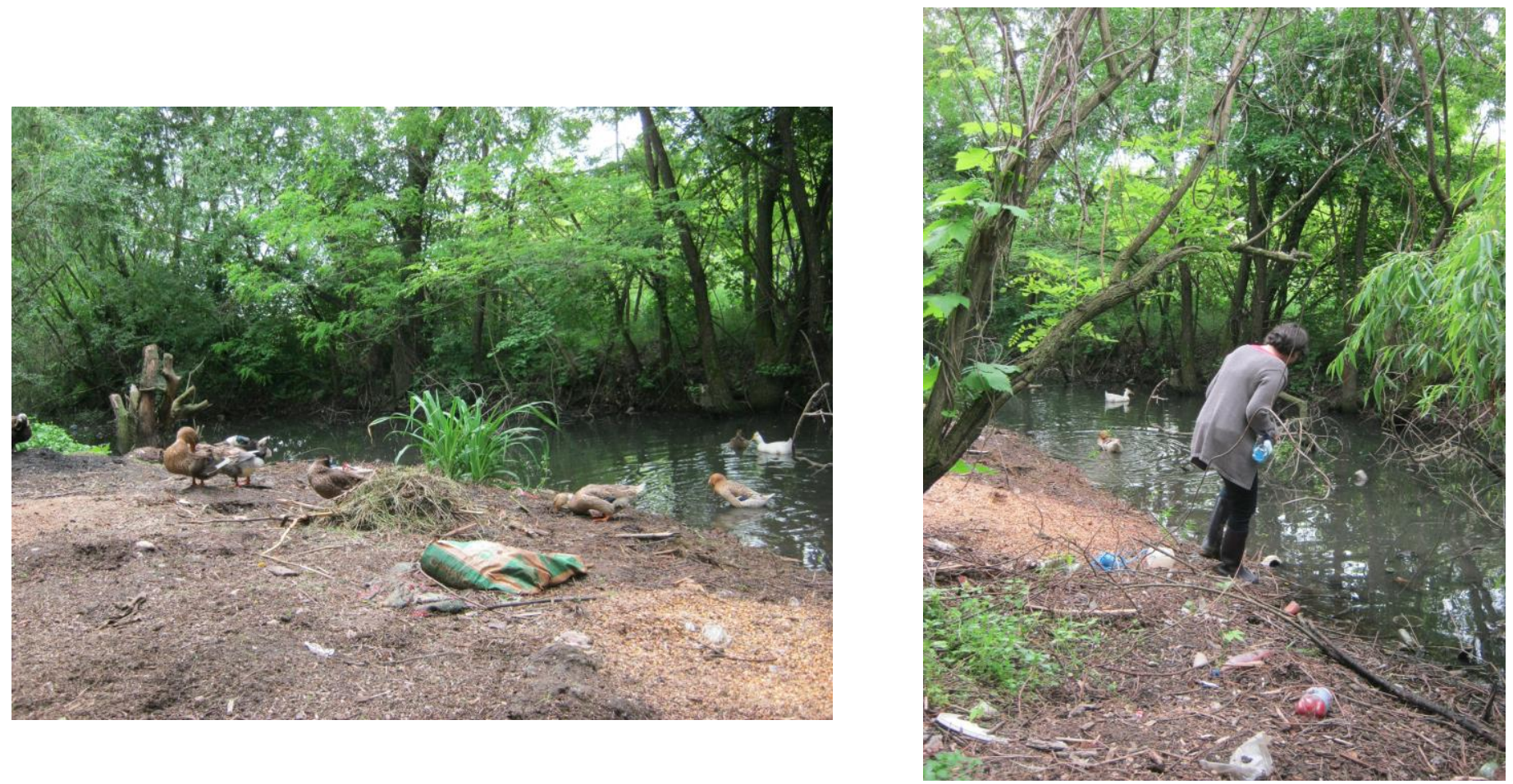

Fig no.2 - Status of the one of the water courses studied

- information of the population about the problems at the local level, about the efforts to overcome them and about obligations of citizens sake of the environment;

- recourse to specialists for project preparation in the environment;

- the need for professional development of people who carry out activities directly related to the natural environment (agriculture, forestry etc.) and other activities such as tourism, for example;

- guidance of children in rural areas, especially early as school, to the agricultural education;

- great attention to the problems of nature and landscape;

- identification of human and financial resources at the local level and central to solving environmental problems, identifying partnerships and associations that can facilitate projects;

- consideration of any environmental issues, even apparently insignificant, solving problems step by step; identifying solutions simple, effective and cheap, which can be applied with local financial and workforce resources [2, $3,4,5,6,7,8,9,10,11]$. 
As solutions to solve the punctual environmental problems we mention:

- development of the basic rural and agricultural infrastructure (with the components mentioned above, at problems identified);

- rational utilization of inputs on agricultural land, depending on the needs of the land, of the cultures, considering the cycles of vegetation and climate factors or the use of less polluting inputs;

- use of extensive agriculture forms;

- stimulating agricultural practices targeted towards not only high yields but also to maintain the natural beauty and peculiarity of the rural landscape and to preserve active rural communities, maintaining and developing the occupancy level of workforce;

- cultivation of plants that have the capacity to depollute the soil;

- scientific practice of crop rotation for improving the soil quality;

- diversification of agricultural production;

- recycling organic waste through agricultural use based on scientific information in the field

- careful control of potentially polluting activities;

- development of land improvement works, through specific measures, aiming to prevent, reduce and eliminate processes of land damage caused by natural factors - drought, floods, excess moisture - or human actions.

The results of this study could form the basis for developing an management model of the specific environment issues in rural space from Romania

\section{References (selection)}

1. Charta europeana a spatiului rural: despre conservarea si protectia mediului http://www.presalocala.com/2011/08/31/charta-europeana-a-spatiului-rural-despreconservarea-si-protectia-mediului/

2. Agenția Națională pentru Protecția Mediului ANPM - Reglementari http://rnges.anpm.ro/Mediu/reglementari-16

3. Dona, I., Dobre, C., Gergely, S. - Dezvoltare Rurala (Note de curs; Sinteze) http://www.managusamv.ro/fisiere/file/dezvoltare\%20rurala\%20draft\%20ide.pdf

4. Brinzan, O., Dezvoltare rurala, Ed. Universitatii "Aurel Vlaicu" Arad, Arad, 2006

5. Raport național privind starea mediului anul 2012 http://rnges.anpm.ro/upload/116008_RSM-2012.pdf

6. Protecţia solului, ecosistemelor şi păstrarea biodiversităţii https://www.academia.edu/10068914/Protec\%C5\%A3ia_solului_ecosistemelor_\%C5\%9 Fi_p\%C4\%83strarea_biodiversit\%C4\%83\%C5\%A3ii_4.1Degradarea_\%C5\%9Fi_poluar ea_solului]

7. Strategia naţională de gestionare a deşeurilor - www.juridice.ro/wp-content/.../03/201301-18-DGDSP-SNGD_v2.doc

8. Raport de mediu - Program Operational Infrastructura Mare - http://www.fonduriue.ro/res/filepicker_users/cd25a597fd-62/2014-2020/po/poim/poimrev3.pdf

9. PNDR 2014-2020 - analiza SWOT Generală , v.2 August 2013 http://eufinantare.info/docs/analiza-swot-generala-pndr-2014-2020-vers2.pdf

10. ROSCI0106 Lunca Mijlocie a Argeşului - http://dev.adworks.ro/natura/situri/215/LuncaMijlocie-a-Argeului.html

11. PUG - Reactualizare Plan Urbanistic General - Comuna Costestii din Vale, Judetul Dambovita 2013, http://www.cjd.ro/PUG/localitati/Costestii\%20din\%20Vale/VOLUMUL\%201\%20\%20Piese\%20scrise\%20PUG/3\%20Memoriu\%20PUG\%20Costestii\%20din\%20Vale_20 14.pdf 